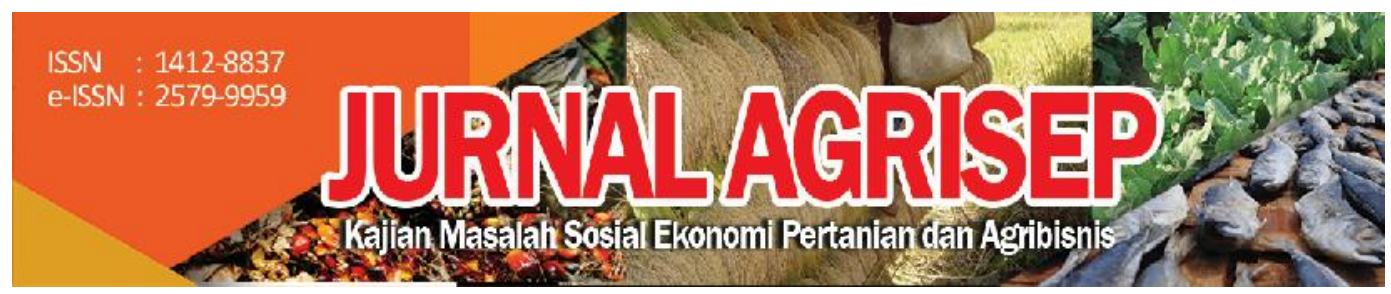

DOI: $10.31186 /$ jagrisep.18.2.269-278

\title{
ANALISIS KEUNTUNGAN PADA USAHATANI PADI SAWAH TADAH HUJAN DAN KONTRIBUSINYA TERHADAP PENDAPATAN RUMAH TANGGA PETANI DI KECAMATAN JANGKAT KABUPATEN MERANGIN
}

Analysis Of Profit In Upland Rice Farming And Its Contribution To The
Farmer's Household Income In Jangkat Subdistrict Of Merangin District

\author{
Emy Kernalis, Arsyad Lubis, Riri Oktari Ulma $\square$ \\ Jurusan Agribisnis Fakultas Pertanian Universitas Jambi \\ Email: ryryady_ulma@yahoo.com
}

\begin{abstract}
Jangkat District is one of the districts which is the center for producing rice in Merangin Regency. Determination of the research's location was conducted purposively, namely Muara Madras Village and Pulau Tengah Village, which are the two villages with the largest rice field planting area in Jangkat District. Sampling in this study using the simple random sampling method or a simple random method in which all of population has the opportunity to be used as a research sample and obtained as many as 57 samples. The purpose of this study were (1) To determine the benefits of lowland rice farming in Jangkat District, Merangin District and (2) to determine the contribution of lowland rice farming to household income of farmers in Jangkat District, Merangin Regency. Profit analysis results show that the average revenue of farmer on rice farming is Rp. 10,749,401/ha. While the average total cost, both real and calculated, is $R p$. $8,098,506 / \mathrm{ha}$. So that the average profit obtained from rice farming is Rp. 2,650,895/ha. Contribution of lowland rice farming to household income is only $4.63 \%$. While the contribution of coffee farming revenue was $7.53 \%$, potatoes $69.78 \%$, and chili $18.06 \%$. Which means that rice farming contributes the smallest compared to other farms.
\end{abstract}

Key Words : Profit, Rice Farming, Household Income

\section{ABSTRAK}

Kecamatan Jangkat merupakan salah satu kecamatan yang menjadi sentra penghasil padi sawah di Kabupaten Merangin. Penentuan lokasi penelitian ini dilakukan 
secara segaja (purposive) yakni Desa Muara Madras dan Desa Pulau Tengah yang mana kedua desa ini menjadi desa dengan luas tanam padi sawah terbesar di Kecamatan Jangkat. Penarikan sampel dalam penelitian ini menggunakan metode simple random sampling atau metode acak sederhana yang mana seluruh populasi berpeluang untuk dijadikan sebagai sampel penelitian dan diperoleh sebanyak 57 sampel. Tujuan penelitian ini adalah (1) Untuk mengetahui keuntungan usahatani padi sawah di Kecamatan Jangkat Kabupaten Merangin dan (2) untuk mengetahui kontribusi usahatani padi sawah terhadap pendapatan rumah tangga petani di Kecamatan Jangkat Kabupaten Merangin. Hasil analisis Keuntungan menunjukkan bahwa rata-rata penerimaan petani pada usahatani padi sebesar Rp. 10.749.401/ha. Sedangkan rata-rata total biaya baik yang riil maupun yang diperhitungkan sebesar Rp. 8.098.506/ha. Sehingga diperoleh rata-rata keuntungan usahatani padi sawah sebesar Rp. 2.650.895/ha. Kontribusi Usahatani padi sawah terhadap pendapatan rumah tangga yakni hanya mencapai 4,63\%. Sedangkan kontribusi pendapatan usahatani kopi 7,53\%, kentang 69,78\%, dan cabe $18,06 \%$. Yang berarti usahatani padi sawah memberikan kontribusi terkecil dibanding dengan usahatani lainnya.

\section{Kata Kunci : Keuntungan, Usahatani, Pendapatan Rumah Tangga}

\section{PENDAHULUAN}

Sektor petanian memiliki peranan penting dimana salah satu sub sektor pertanian adalah tanaman pangan, betapa tidak, pangan merupakan kebutuhan hidup masayarakat terlebih lagi beras yang masih menjadi makanan pokok masyarakat Indonesia. Padi sawah masih menjadi jenis padi yang mendominasi pertanian padi di Indonesia. Produksi padi sawah pada angka sementara tahun 2017 sebesar 77.603.000 Ton dengan laju pertumbuhan dibandingkan Tahun 2016 sebesar 2,81 \%. Sementara itu Provinsi Jambi mencapai produksi padi sawah pada angka sementara Tahun 2017 sebesar 142.067 Ton dengan laju pertumbuhan produksi dibandingkan tahun 2016 sebesar 6,82 \% (Badan Pusat Statistik Nasional, 2017)

Keberadaan tanaman padi sawah Provinsi Jambi didukung oleh beberapa Kabupaten yang menjadi kabupaten penghasil padi sawah, salah satunya adalah Kabupaten Merangin. Selama beberapa tahun terakhir Kabupaten Merangin mengalami meningkatan produksi usahatani padi sawah, hal itu dapat terlihat pada Tabel 1. 
Tabel 1. Luas Panen, Produksi dan Produktivitas Padi Sawah Menurut Kecamatan di Kabupaten Merangin Tahun 2016

\begin{tabular}{llrrr}
\hline No & \multicolumn{1}{c}{ Kecamatan } & $\begin{array}{c}\text { Luas Panen } \\
\text { (Ha) }\end{array}$ & $\begin{array}{c}\text { Produksi } \\
\text { (Ton) }\end{array}$ & $\begin{array}{r}\text { Produktivitas } \\
(\mathrm{Kw} / \mathrm{Ha})\end{array}$ \\
\hline $\mathbf{1}$ & Jangkat & 2.015 & 12.065 & 59,88 \\
2 & Sungai Tenang & 2.021 & 12.061 & 59,67 \\
3 & Bangko & 7 & - & - \\
4 & Bangko Barat & 28 & 108 & 39,00 \\
5 & Nalo Tantan & - & - & - \\
6 & Batang Masumai & 144 & 637 & 44,12 \\
7 & Pamenang & 957 & 4.753 & 49,69 \\
8 & Pamenang Barat & 109 & 539 & 49,59 \\
9 & Renah Pamenang & 72 & - & - \\
10 & Pamenang Selatan & 193 & 840 & 43,59 \\
11 & Muara Siau & 178 & 766 & 43,05 \\
12 & Lembah Masurai & 165 & 855 & 51,84 \\
13 & Tiang Pumpung & 3 & 12 & 39,24 \\
14 & Sungai Manau & 1.327 & 7.095 & 53,45 \\
15 & Renah Pembarap & 453 & 2.115 & 46,73 \\
16 & Pangkalan Jambu & 683 & 3.333 & 48,81 \\
17 & Tabir & 3.449 & 20.316 & 58,90 \\
18 & Tabir Ulu & 1.653 & 9.085 & 54,95 \\
19 & Tabir Selatan & 204 & 872 & 42,80 \\
20 & Tabir Ilir & 138 & 610 & 44,11 \\
21 & Tabir Timur & 206 & 926 & 44,87 \\
22 & Tabir Lintas & 192 & 773 & 40,31 \\
23 & Margo Tabir & 1.376 & 6.661 & 48,42 \\
24 & Tabir Barat & 327 & 1.374 & 42,01 \\
\hline & Jumlah / Total & 15.900 & 85.796 & 53,96 \\
\hline
\end{tabular}

Sumber : Kabupaten Merangin Dalam Angka, 2017

Tabel 1 menunjukan bahwa luas panen terbesar terdapat di Kecamatan Tabir yakni seluas 3.449 ha, produkti tertinggi juga terletak di Kecamatan Tabir yakni sebesar 20.316 Ton, namun produktivitas tertinggi terletak di Kecamatan Jangkat yakni sebesar 59,88 kwintal per hektar. Hal ini menunjukkan bahwa Kecamatan Jangkat memiliki lahan yang sangat produktif untuk melakukan usahatani padi sawah sehingga menghasilkan produktivitas yang tinggi. Adapun perkembangan luas panen, produksi dan produktivitas Kecamatan Jangkat hingga tahun 2016 dapat dilihat pada Tabel 2. 
Tabel 2. Luas Panen, Produksi dan Produktivitas Padi Sawah Kecamatan Jangkat Tahun 2011-2016

\begin{tabular}{cccc}
\hline Tahun & Luas Panen $(\mathrm{Ha})$ & Produksi (Ton) & Produktivitas $(\mathrm{Kw} / \mathrm{Ha})$ \\
\hline 2011 & 1.386 & 5.538 & 39,96 \\
2012 & 1.442 & 5.762 & 39,96 \\
2013 & 2.110 & 9.105 & 43,15 \\
2014 & 1.557 & 7.341 & 47,15 \\
2015 & 1.340 & 6.610 & 49,33 \\
2016 & 2.015 & 12.065 & 59,88 \\
\hline
\end{tabular}

Sumber : Kecamatan Jangkat Dalam Angka, 2017

Pada Tabel 2 terlihat bahwa pada Tahun 2016 terjadi peningkatan secara signifikan dari sisi luas panen, produksi maupun produktivitas padi sawah di Kecamatan Jangkat. Hal ini didukung oleh kondisi geografis Kecamatan Jangkat yang menguntungkan bagi usaha pertanian. Kecamatan Jangkat merupakan salah satu wilayah tertinggi di Kabupaten Merangin yang merupakan daerah perbukitan dan pegunungan dengan ketinggian wilayah 700-1.300 meter dari permukaan laut (Statistik Daerah Kecamatan Jangkat, 2016). Wilayah pegunungan dikenal sangat baik untuk berbagai aktivitas pertanian termasuk usahatani padi sawah.

Petani di Kecamatan Jangkat seluruhnya mengusahakan usahatani padi sawah karena telah menjadikannya sebagai budaya yang dijalankan secara turun temurun. Hasil padi sawah tersebut kemudian digunakan untuk kebutuhan sehari-hari dan tidak menjualnya sebab sebagian besar petani memiliki pendapatan dari usahatani non padi sawah seperti kopi, kulit manis, kentang, cabai dan lain-lain. Penghasilan dari usahatani non padi sawah tersebut digunakan untuk memenuhi kebutuhan keluarga. Sebagai usahatani yang dilakukan oleh setiap rumah tangga di Kecamatan Jangkat, usahatani padi sawah tentu saja juga memiliki kontribusi yang sangat bersar bagi pemenuh kebutuhan ekonomi keluarga. Terdapat keuntungan yang diterima oleh petani dalam menjalankan usahatani padi sawah jika keseluruhan aktivitas usahatani diasumsikan sebagai kegiatan yang bernilai ekonomi. Selain itu usahatani padi sawah tentu saja juga memberi kontribusi terhadap pendapatan setiap rumah tangga petani di Kecamatan Jangkat.

\section{METODE PENELITIAN}

\section{Tempat dan Waktu}

Penelitian ini dilakukan di Muara Madras dan Pulau Tengah Kecamatan Jangkat Kabupaten Merangin. Alasan pemilihan lokasi dilakukan secara sengaja 
(Purposive) didasarkan pada kegiatan usahatani padi sawah tadah hujan yang sampai saat ini masih dilakukan didaerah setempat.

\section{Pengambilan responden}

Penentuan responden yang diteliti menggunakan metode acak sederhana (Simple Random Sampling Method) dimana seluruh populasi sampel memiliki peluang yang sama untuk dipilih sebagai sampel. Desa yang akan dijadikan sampel yakni Desa Muara Madras yang terdapat 13 kelompok tani dengan 379 anggota, kemudian Desa Pulau Tengah yang terdapat 8 kelompok tani dengan 118 anggota. Berdasarkan hasil perhitungan, sampel diperoleh sebanyak 57 petani. Selanjutnya jumlah sampel yang akan dijadikan sebagai responden pada masing-masing desa ditentukan dengan metode alokasi sampel profesional.

\section{Pengumpulan data}

Jenis data yang digunakan dalam penelitian ini adalah data primer dan data sekunder. Data primer adalah data yang diperoleh atau dikumpulkan dari sumber aslinya tanpa melalui perantara untuk menjawab masalah atau tujuan penelitian. Dalam penelitian ini, data primer dapat diperoleh dari petani padi sawah melalui wawancara langsung dengan menggunakan daftar pertanyaan (kuisioner). Adapun data sekunder merupakan data yang sudah tersedia sehingga kita tinggal mencari dan menggumpulkan. Data sekunder dapat kita peroleh dengan lebih mudah dan cepat karena sudah tersedia. Data yang dapat diperoleh dari instansi terkait dengan penelitian, literatur dan hasil-hasil penelitian sebelumnya yang erat hubungannya dengan permasalahan yang diteliti.

\section{Analisis data}

Metode analisis data yang digunakan dalam penelitian ini adalah analisis penelitian deskriptif dan analisis kuantitatif. Analisis deskriptif digunakan untuk menggambarkan kondisi dan situasi dalam penelitian yang berbentuk pernyataan-pernyataan, yang dilukiskan dengan perkataan serta untuk melihat gambaran umum dan karakteristik responden dalam penelitian ini (petani sampel).

Keuntungan usahatani padi sawah dapat dihitung dengan menggunakan formulasi sebagai berikut (Soekartawi, 1995) :

$$
\begin{aligned}
& \pi=T R-T C \\
& \pi=\left(Y \times P_{y}\right)-(T F C+T V C)
\end{aligned}
$$

Dimana: $\pi$ adalah Keuntungan usahatani padi sawah (Rp/tahun/ha); TR adalah Total penerimaan usahatani padi sawah (Rp/tahun/ha); TC adalah Total biaya usahatani padi sawah ( $\mathrm{Rp} /$ tahun/ha); Y adalah Produksi padi sawah 
(Kg/ha/tahun); Py adalah Harga padi sawah (Rp/kg); TFC adalah Biaya tetap total (Rp/tahun/ha); dan TVC adalah Biaya variabel total (Rp/tahun/ha) Efisiensi usahatani dihitung dengan menggunakan $\mathrm{R} / \mathrm{C}$ ratio. $\mathrm{R} / \mathrm{C}$ merupakan perbandingan antara jumlah total penerimaan dengan jumlah total biaya yang dikeluarkan selama satu periode. Suatu usaha dinilai menguntungkan atau secara ekonomis efisien jika $\mathrm{R} / \mathrm{C}$ rasio $>1$. Selanjutnya, $\mathrm{R} / \mathrm{C}$ ratio $<1=$ Berarti usaha yang dilakukan secara ekonomis tidak efisien atau tidak menguntungkan dan $\mathrm{R} / \mathrm{C}$ ratio $=1=$ Berarti usaha mengalami titik impas

$$
R / C \text { ratio }=\frac{\mathrm{TR}}{\mathrm{TC}}
$$

dimana $\mathrm{R} / \mathrm{C}$ ratio = Perbandingan antara penerimaan dan biaya; TR dan TC telah didefinisikan di atas.

Untuk mengetahui kontribusi pendapatan usahatani padi sawah terhadap pendapatan rumah tangga usahatani berdasarkan persentasi, dengan pendekatan :

$$
A=\frac{B}{C} \times 100 \%
$$

dimana A adalah Kontribusi Usahatani Padi Sawah; B adalah Pendapatan Usahatani Padi Swaah; dan C adalah Total Pendapatan Usahatani Rumah Tangga

\section{HASIL DAN PEMBAHASAN}

\section{Karakteristik Petani Sampel}

Identitas petani dalam penelitian ini dibatasi pada beberapa karakteristik yang diperkirakan dapat mempengaruhi kemampuan petani dalam berusahatani. adapun kriteria yang dimaksud adalah umur petani, tingkat pendidikan, jumlah anggota keluarga dan pengalaman dalam berushatani.

Tabel 3. Identitas Petani Sampel di daerah Penelitian

\begin{tabular}{lccc}
\hline \multicolumn{1}{c}{ Identitas Petani } & Rata-rata & Frekuensi & Persentase \\
\hline Umur Petani (Tahun) & $37-50$ & 25 & 43,86 \\
Jumlah Anggota Keluarga (orang) & $3-4$ & 27 & 47,36 \\
Tingkat Pendidikan & SMP/SMA & 36 & 63,16 \\
Pengalaman Berusahatani (Tahun) & $16-22$ & 14 & 24,57 \\
\hline
\end{tabular}

Berdasarkan tabel 3 diketahui bahwa rata-rata umur petani memiliki frekuensi terbanyak adalah umur 35 - 47. Hal ini menunjukkan bahwa rata-rata berada pada usia produktif. Umur memegang peranan penting dalam berusahatani. Soeharjo dan Patong (1973) menyatakan bahwa umur adalah 
identitas yang dapat mempengaruhi pola pikir seseorang, semakin tua umur seseorang akan semakin matang cara berfikirnya untuk mengatasi masalah.

Rata-rata jumlah anggota keluarga petani adalah 3-4 orang, petani dengan jumlah tanggungan lebih besar maka kebutuhan keluarga akan lebih besar pula. Hernanto (1998), mengatakan bahwa besarnya anggota keluarga akan berpengaruh dalam kegiatan usahataninya, petani yang memiliki keluarga yang besar akan memakainya untuk kegiatan usahataninya, sehingga tidak memakai tenaga upahan.

Tingkat pendidikan, menurut Hernanto (1998), keterbatasan tingkat pendidikan akan mempengaruhi cara berfikir, menerima, ataupun menolak halhal baru. Tingkat pendidikan juga akan berpengaruh terhadap kecerdasan dalam hal menerima sesuatu yang baru atau penemuan baru, hal ini dikarenakan pendidikan bertujuan merubah sikap dan tingkah laku manusia. Rata-rata tingkat pendidikan petani adalah SMP dan SMA, relatif tingginya tingkat pendidikan akan berpengaruh pada tingginya keterampilan adopsi teknologi petani dalam mengelola usahataninya.

Pengalaman seseorang dapat dijadikan tolak ukur untuk pengembangan dimasa yang akan datang. Pengalaman yang diperoleh dalam berusahatani dapat mempengaruhi kemampuan dalam mengelola maupun mengambil keputusan bagi pengelolaan usahataninya. Menurut Hernanto (1998), makin tinggi pendidikan dan pengalaman petani maka akan berhati-hati serta menghitung kemungkinan resiko yang akan dihadapi. Rata-rata pengalaman berusahatani petani di daerah penelitian cukup lama yaitu 16-22 tahun, lamanya pengalamam berusahatani ini juga akan berpengaruh terhadap pola piker dalam pengambilan keputusan .

\section{Keuntungan Usahatani Padi Sawah}

Keberhasilan dari suatu usahatani dapat dilihat dari pendapatan usahataninya. Pendapatan usahatani berarti mengukur imbalan yang diperoleh petani dari penggunaan faktor-faktor produksi, pengolahan dan modal yang digunakan. Pendapatan petani yang dimaksud dalam penelitian ini adalah pendapatan bersih atau keuntungan yang diterima oleh petani dalam satu kali musim tanam. Rata-rata pendapatan usahatani padi di daerah penelitian dapat dilihat pada Tabel 4. 
Tabel 4. Rata-rata Pendapatan Usahatani Padi di daerah penelitian

\begin{tabular}{|c|c|c|}
\hline \multirow{2}{*}{ Input } & \multicolumn{2}{|c|}{ Biaya Rata-Rata $(\mathrm{Rp} / \mathrm{Ha})$} \\
\hline & Riil & Diperhitungkan \\
\hline Sewa Lahan & 0 & 2.719 .611 \\
\hline Benih & 0 & 847.904 \\
\hline TKDK & 0 & 1.832 .335 \\
\hline TKLK & 1.204 .152 & 0 \\
\hline Pupuk & 149.869 & 0 \\
\hline PHPT & 38.740 & 0 \\
\hline Sewa Mesin Bajak & 881.206 & 0 \\
\hline Sewa Mesin Perontok & 369.072 & 0 \\
\hline Penyusutan Alat & 55.617 & \\
\hline Biaya Total & 2.698 .656 & 5.399 .850 \\
\hline Penerimaan $\left(\sum\right.$ Produksi $x$ Harga $)$ & \multicolumn{2}{|c|}{10.749 .401} \\
\hline Pendapatan Riil = Penerimaan - Biaya Riil & \multicolumn{2}{|c|}{8.050 .895} \\
\hline $\begin{array}{l}\text { Pendapatan Diperhitungkan = Penerimaan } \\
\text { - (Biaya Riil + Biaya Diperhitungkan) }\end{array}$ & \multicolumn{2}{|c|}{2.650 .895} \\
\hline
\end{tabular}

Tabel 4 dapat dilihat bahwa rata-rata pendapatan yang diperhitungkan atau pendapatan bersih perhektar di daerah penelitian sebesar Rp. 2.650.895. Pendapatan tersebut diperoleh dari selisih total penerimaan (Rp. 10.749.401) dengan total biaya riil dan diperhitungkan (Rp. 8.098.506).. Dengan kata lain keuntungan usahatani padi sawah di Kecamatan Jangkat Kabupaten Merangin cukup memberikan keuntungan, hal ini dapat dilihat dari rasio penerimaan dan biaya lebih besar dari 1 yaitu dari biaya riil sebesar 3,98 dan dari biaya riil dan diperhitungkan sebesar 1,33. Hasil penelitian sejalan dengan hasil penelitian Rosvita 2012, Ginting 2014 yang menyatakan usahatani padi sawah yang dilakukan memberikan keuntungan dilihat dari rasio penerimaan dan biaya (R/C).

\section{Kontribusi Pendapatan Usahatani Padi terhadap Total Pendapatan Rumah Tangga}

Penelitian menunjukkan bahwa petani di daerah penelitian tidak hanya mengusahakan satu jenis komoditi. Jenis komoditi yang diusahakan oleh petani di daerah penelitian terdiri atas padi, kopi, kentang, dan cabe. Umumnya semakin banyak jenis komoditi yang diusahakan para petani maka semakin besar pendapatan yang akan diperoleh. Ini juga tidak terlepas dari jenis dan luas lahan yang diusahakan petani. jumlah komoditi yang diusahakan petani memiliki luas lahan yang beranekaragam. Pendapatan diperoleh dari berbagai 
jenis usahatani tersebut sangar tergantung dengan berbagai faktor, antara lain jumlah produksi yang dihasilkn dan harga yang berlaku di tingkat petani.

Kontribusi adalah sumbangan atau dalam penelitian dimaksudkan sebagai besarnya bagian pendapatan yang disumbangkan dari usahatani padi sawah terhadap total pendapatan rumah tangga. Usahatani rumah tangga di daerah penelitian berasal dari usahatani padi, kopi, kentang dan cabe. Kontribusi masing-masing usahatani terhadap total pendapatan rumah tangga dapat dilihat pada tabel berikut ini :

Tabel 5. Kontribusi Padi terhadap Pendapatan Rumah Tangga di Daerah Penelitian

\begin{tabular}{|c|c|c|}
\hline Jenis Komoditi & Pendapatan (Rp) & Kontribusi (\%) \\
\hline Padi & $8.050 .895,00$ & 4,63 \\
\hline Kopi & $13.178 .603,09$ & 7,53 \\
\hline Kentang & $122.081 .800,00$ & 69,78 \\
\hline Cabe & $31.590 .500,00$ & 18,06 \\
\hline Jumlah & $176.012 .368,69$ & 100,00 \\
\hline
\end{tabular}

Tabel 5 menunjukkan bahwa kontribusi pendapatan usahatani padi sawah terhadap pendapatan rumah tangga hanya sebesar $4,63 \%$. Sedangkan kontribusi pendapatan masing-masing usahatani kopi sebesar 7,53\%, kentang sebesar $69,78 \%$, dan cabe sebesar 18,06\%. Artinya kontribusi komoditi padi memberikan persentase terkecil dari sumber-sumber pendapatan rumah tangga di Kecamatan jangkat. Hal ini tidak sesuai dan bertolak belakang dengan penelitian Gapri Anton danMarhawati (1916), dimana kontribusi tanaman padi memberikan kontribusi terbesar dalam pendapatan rumah tangga petani.

\section{SIMPULAN DAN SARAN}

\section{Simpulan}

Simpulan yang dapat diperoleh bahwa 1) Hasil analisis keuntungan menunjukkan bahwa rata-rata penerimaan petani pada usahatani padi sebesar Rp. 10.749.401/ha. Sedangkan rata-rata total biaya yang digunakan sebesar Rp.8.098.506/ha. Sehingga diperoleh rata-rata keuntungan usahatani padi sawah sebesar Rp. 2.650.895/ha. 2) Kontribusi Usahatani padi sawah terhadap pendapatan rumah tangga yakni hanya mencapai $4,63 \%$. Sedangkan kontribusi pendapatan usahatani kopi 7,53\%, kentang 69,78\%, dan cabe 18,06\%. Dengan berarti usahatani padi sawah memberikan kontribusi terkecil dibanding usahatani lainnya. 


\section{Saran}

Adapun saran yang dpat diberikan bagi pertani adalah, peggunaan input sesuai anjuran dan penerapan teknik budidaya yang tepat, maka akan memberikan produksi yang meningkat. Sementara itu, bagi pemerintah, perlu dilakukan penyuluhan bagi petani terkait penerapan teknologi untuk peningkatan produksi, pemberian subsidi input sehingga mendorong motivasi petani dalam berusahatani padi.

\section{DAFTAR PUSTAKA}

Badan Pusat Statistik Nasional. 2017. Padi Nasional. Badan Pusat Statistik Nasional . 2017. Kabupaten Merangin Dalam Angka. Badan Pusat Statistik Kabupaten Merangin. . 2017. Statistik Daerah Kecamatan Jangkat. Badan Pusat Statistik Kabupaten Merangin

Soeharjo dan Patong. 1973. Ilmu Usahatani

Soekartawi. 1994. Teori Ekonomi Produksi dengan Pokok Bahasan Analisis Fungsi Cobb Douglas. PT. Raja Grafindo Persada, Jakarta

Gapri Anton. M dan Marhawati. 2016. Kontribusi Usahatani Padi SawahTerhadap Pendapatan Usahatani Keluarga Di Desa Ogoamas Ii Kecamatan Sojol Utara Kabupaten Donggala. Universitas Tadulako

Hernanto, Fadholi. 1998. Ilmu Usaha Tani. Penebar Swadaya, Jakarta. 